\title{
Zoanthids of the Cape Verde Islands and their symbionts: previously unexamined diversity in the Northeastern Atlantic
}

\author{
James D. Reimer ${ }^{1,2,4}$,Mamiko Hirose ${ }^{1}$, Peter Wirtz ${ }^{3}$ \\ ${ }^{1}$ Molecular Invertebrate Systematics and Ecology Laboratory, Rising Star Program, Transdisciplinary Research \\ Organization for Subtropical Island Studies (TRO-SIS), University of the Ryukyus, Senbaru 1, Nishihara, Okinawa \\ 903-0213, Japan \\ ${ }^{2}$ Marine Biodiversity Research Program, Institute of Biogeosciences, Japan Agency for Marine-Earth Science and \\ Technology (JAMSTEC), 2-15 Natsushima, Yokosuka, Kanagawa 237-0061, Japan \\ ${ }^{3}$ Centro de Ciências do Mar, Universidade do Algarve, Campus de Gambelas, PT 8005-139 Faro, Portugal \\ ${ }^{4}$ E-mail: jreimer@sci.u-ryukyu.ac.jp
}

Key words: Cape Verde Islands, Cnidaria, Symbiodinium, undescribed species, zoanthid

\begin{abstract}
The marine invertebrate fauna of the Cape Verde Islands contains many endemic species due to their isolated location in the eastern Atlantic, yet research has not been conducted on most taxa here. One such group are the zoanthids or mat anemones, an order of benthic cnidarians (Hexacorallia: Zoantharia) common in many marine environments. In this study, the diversity of zoanthids in the Cape Verde Islands is specifically examined for the first time. Field images and sampling are combined with molecular phylogenetic analyses utilizing two mitochondrial DNA markers (cytochrome oxidase subunit I and $16 \mathrm{~S}$ ribosomal DNA) to determine the number of species present. Specimens from eight species (Palythoa caribaeorum, Palythoa sp. 265, Zoanthus aff. pulchellus, Isaurus tuberculatus, Parazoanthus sp. 269, Parazoanthus sp. 1401, Antipathozoanthus macaronesicus, Terrazoanthus sp. 276) were identified, including two to four species that are likely new to science. Additional examinations of Symbiodinium endosymbionts in zooxanthellate species showed that clades A, B, and C were present; this is the first report of clade B associating with a zoanthid species. An appendix describing the eight zoanthid species found in the Cape Verde Islands is included to provide a base for future zoanthid research in this region.
\end{abstract}

\section{Contents}

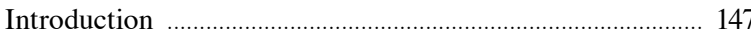

Material and methods ............................................................ 151

Specimen collection and initial identification ................ 151

Specimen nomenclature ..................................................... 151

DNA extraction, PCR Amplification, and sequencing .. 151

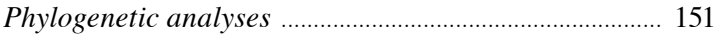

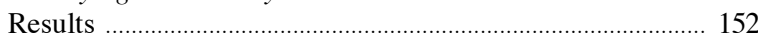

In situ morphological zoanthid identification ................. 152

DNA sequence and phylogenetic identification -

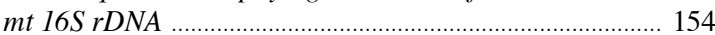

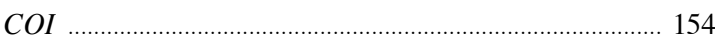

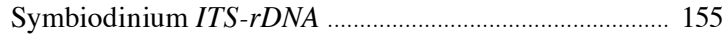

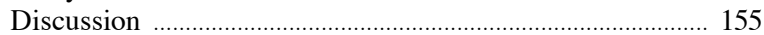

Suborder Brachycnemina ................................................. 155

Suborder Macrocnemina ................................................ 157

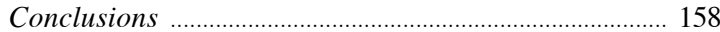

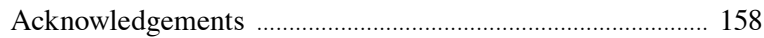

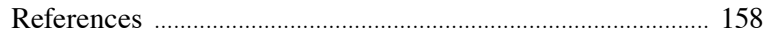

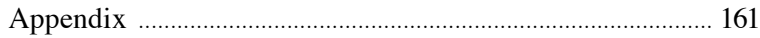

\section{Introduction}

Zoanthids are an order of benthic anthozoans found in most marine environments. Despite their presence in most marine ecosystems, zoanthids remain a taxonomically neglected group due to a relatively simple body plan, a lack of proven species-level diagnostic morphological characteristics, high levels of intraspecific variation (Burnett et al., 1997; Reimer et al., 2004), and encrustations of sand and detritus in their mesoglea (body walls) making internal examinations very problematic (discussed in Reimer et al., 2010). Thus, with a lack of information, overall levels of species diversity remain unknown (Burnett et al., 1997; Reimer et al., 2004).

However, recent examinations of zoanthids from many different locations such as Australia (Burnett et al., 1997), the Galapagos Islands (Reimer et al., 2008c; Reimer and Hickman, 2009), Japan (Reimer, 2007), New Caledonia (Sinniger, 2006), Singapore (Reimer and Todd, 2009), and the Caribbean (Swain, 2009) have shown that a combination of careful in situ observation of substrate and habitat along with the utilization of molecular techniques can accurately ascertain taxonomic identifications and identify 
potential undescribed species. Furthermore, examinations from insular and more isolated oceanic regions such as the Galapagos have demonstrated the presence of potentially endemic or rarely known zoanthids that were simply just in need of discovery (Reimer and Fujii, 2010).

The marine fauna and flora of the Cape Verde Islands is much more tropical in character than the West African coast at the same latitude, where cold upwelling occurs (Türkay, 1982). Morri et al. (2000) gave a preliminary description of the marine zoogeography of the Cape Verde Islands. As pointed out by numerous authors (e.g. Laborel, 1974; Prud'homme van Reine and Van den Hoek, 1988; Wirtz, 2001 and references therein), the marine fauna and flora of the Cape Verde Islands shows a strong amphi-atlantic component. The molluscs (Rolán, 2005), fish (Reiner, 1996; Brito et al., 1999) and some selected groups of Hexacorallia (Boekschoten and Borel Best, 1988) are some marine groups reasonably well studied. Türkay (1982) and Wirtz and D'Udekem d'Acoz (2001) summarized the state of knowledge on decapod crustaceans; Núñez et al. (2000) gave a preliminary list of the polychaetes. Many other marine invertebrate groups lack comprehensive accounts and unrecorded and undescribed species are constantly being discovered (e.g. Opresko, 2003; Freitas and Castro, 2005; Stokvis and van Ofwegen, 2006; Wirtz, 2009). Due to their isolated position about $600 \mathrm{~km}$ off the western tip of Africa, the Cape Verde Islands harbor numerous endemic species (see the species lists mentioned above for examples).

Morri and Bianchi (1995), Morri et al. (2000), and Monteiro et al. (2008) described epibenthic communities at Sal Island and recorded the depth distribution of Palythoa caribaeorum Duchassaing and Michelotti, 1864. There are two historical records of zoanthid species in the Cape Verde Islands, which are mentioned later, in the discussion part of this manuscript. Other recent records of zoanthids from the Cape Verde Islands include 1) xanthid crabs associated with Palythoa (Den Hartog and Holthuis, 1984; Den Hartog and Türkay, 1991), 2) a mention of Zoanthus and Palythoa in Van der Land (1993), 3) a photo of Isaurus tuberculatus Gray, 1828 by the third author, taken near Tarrafal, Santiago Island (Wirtz and Debelius, 2003, page 63, bottom left), and 4) several records discussing the presence of Antipathozoanthus macaronesicus Ocaña and Brito, 2003 (Ocaña and Brito, 2003; Ocaña et al., 2007; Sinniger et al., 2010).

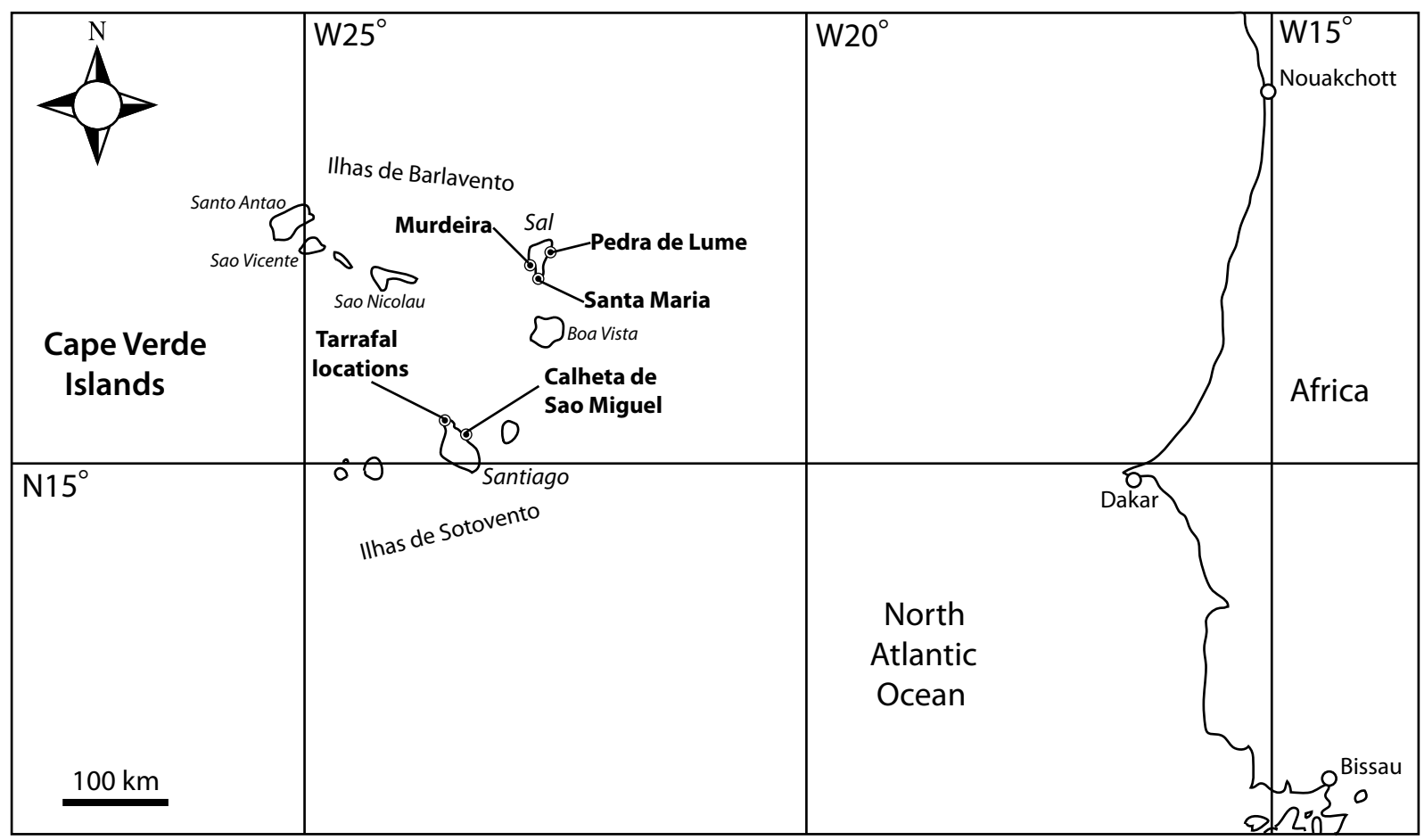

Fig. 1. Map showing location of zoanthid specimen sampling sites in the Cape Verde Islands. Sampling location names in bold, island names in italics. 


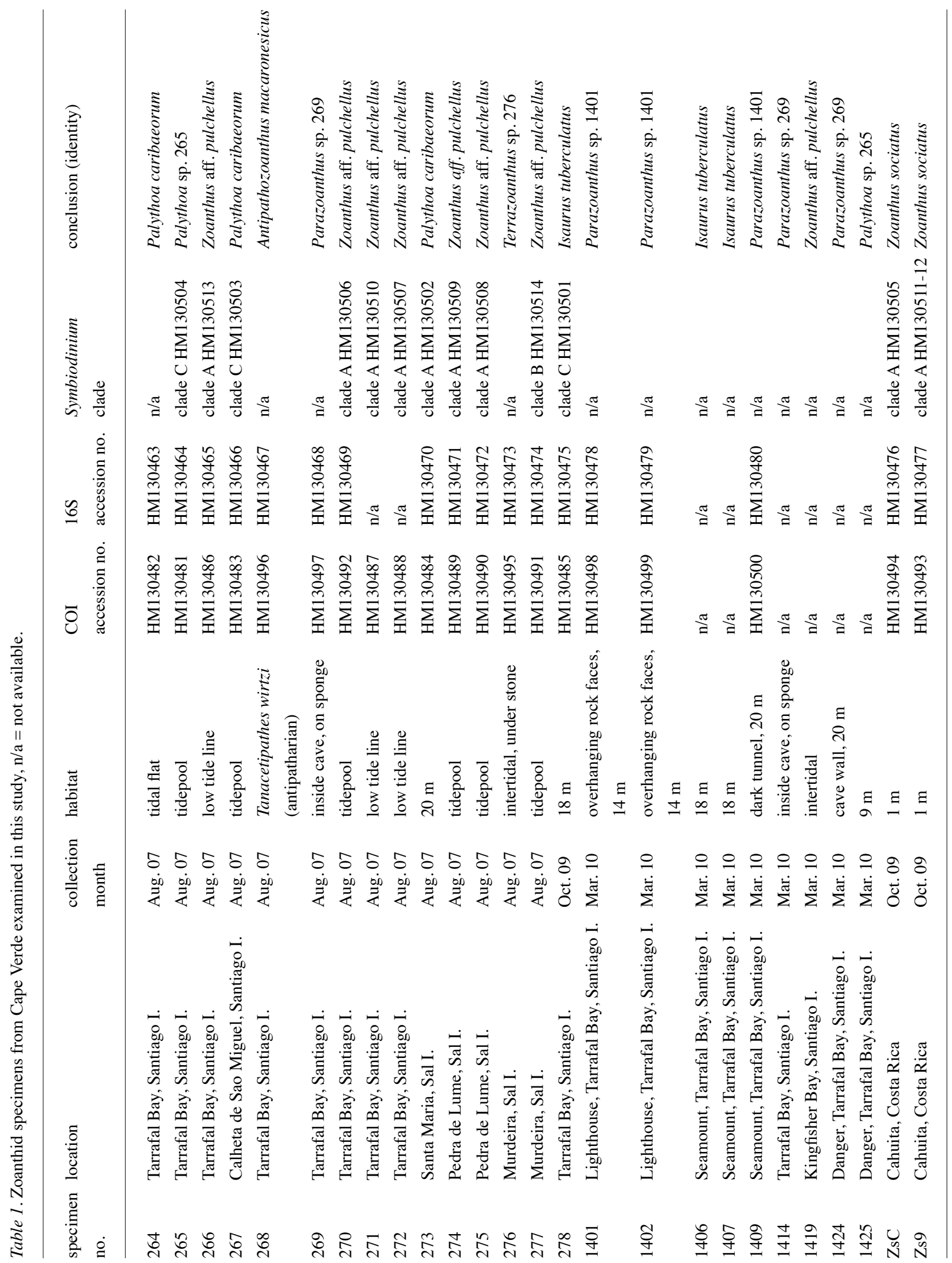



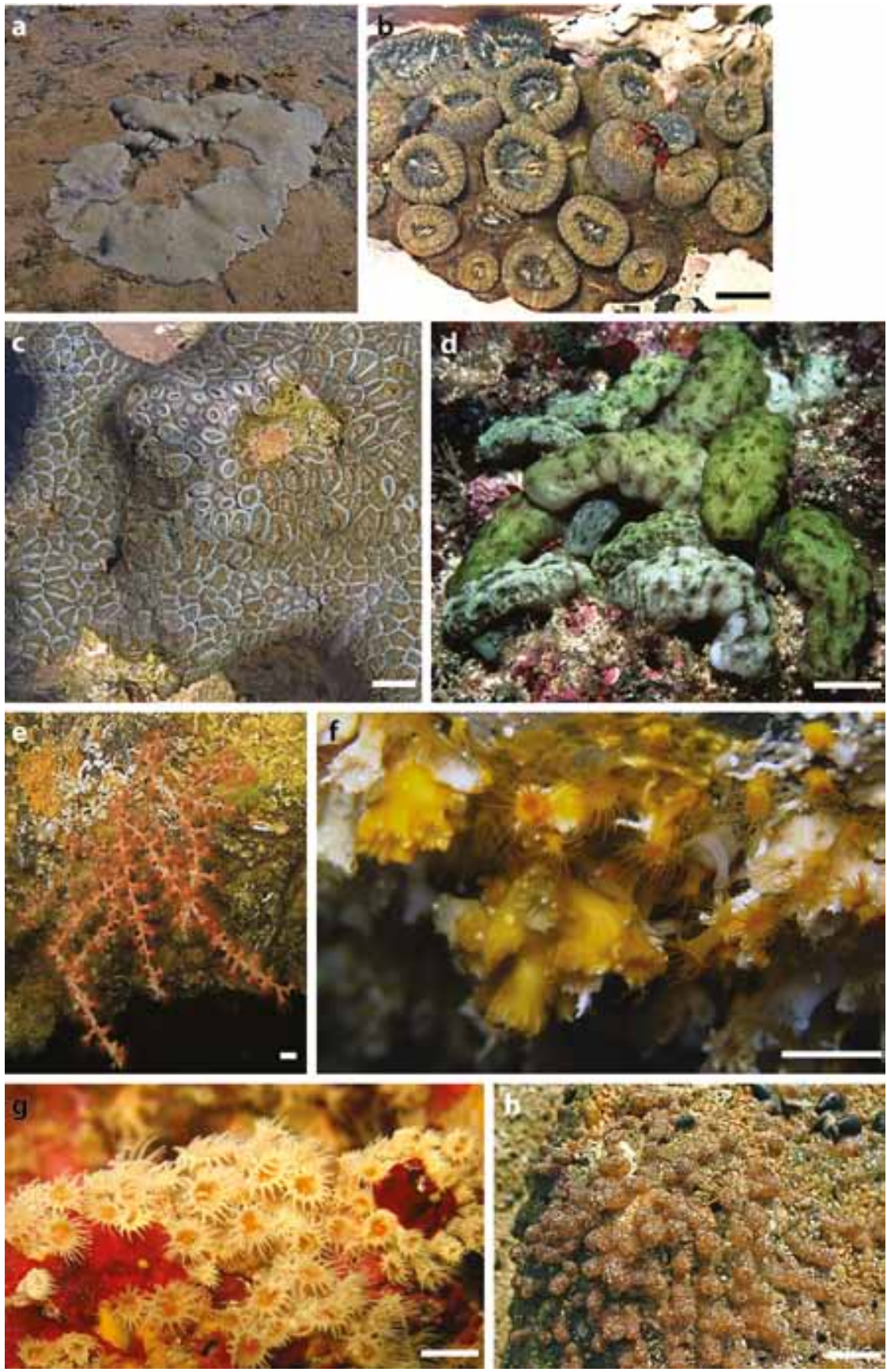

Fig. 2. Zoanthids of the Cape Verde Islands examined in this study. a) Palythoa caribaeorum (specimen 264) in the intertidal zone at Tarrafal Bay, Santiago Island, b) Palythoa sp. 265 (specimen 265) in a tidepool at Tarrafal Bay, Santiago Island, c) Zoanthus aff. pulchellus (specimen 277) in a tidepool at Murdeira Bay, Sal Island, d) Isaurus tuberculatus (specimen not collected) approximately $2 \mathrm{~km}$ north of Tarrafal Bay, Santiago Island, e) Antipathozoanthus macaronesicus (specimen 268) on the antipatharian Tanacetipathes cavernicola at Tarrafal Bay, Santiago Island, f) Parazoanthus sp. 269 (specimen 269) on a sponge at Tarrafal Bay, Santiago Island, g) Parazoanthus sp. 1401 (specimen 1401), at Lighthouse, Tarrafal Bay, Santiago Island, h) Terrazoanthus sp. 276 (with closed polyps; specimen 276) at Murdeira, Sal Island. Scale bars (except Fig. 2a) $=1 \mathrm{~cm}$. For specimen information refer to Table 1 .
In this study we specifically examine the diversity of zoanthids in the Cape Verde Islands for the first time, using both morphologic and molecular techniques, and present a preliminary species list. Additionally, we present data on symbiotic dinoflagellates (Symbiodinium spp.) for zooxanthellate Zoanthus, Isaurus and Palythoa species, as the charac- terization of Symbiodinium can allow us to understand the ecology and biogeography of the holobiont (host + symbiont) (Reimer and Todd, 2009). Our results should provide a basis for future zoanthid and Symbiodinium research in the islands, and allow future comparisons with data from other Atlantic locations. 


\section{Material and methods}

\section{Specimen collection and initial identification}

Twenty-three zoanthid specimens (in this study specimens $=$ colonies) representing all observed zoanthid morphotypes were collected from the intertidal zone or by snorkeling or SCUBA from several locations in the Cape Verde Islands (several Tarrafal Bay locations and Calheta de Sao Miguel on Santiago Island, and Santa Maria, Pedra de Lume and Murdeira on Sal Island Fig. 1) in August 2007, September 2008, and March 2010 (Table 1).

Specimens were preliminarily identified using morphological characteristics used in past literature (e.g. sand-encrusted or not), oral disk color, polyp form, etc. (Table 1, Fig. 2) based on in situ photographs (taken with a Canon Powershot digital camera in an underwater housing) and ex situ physical examination. Specimens were subsequently stored in $96 \%$ ethanol at ambient temperature. All samples were finally deposited at the University of the Ryukyus (Nishihara, Okinawa, Japan) in $99.5 \%$ ethanol at $-20^{\circ} \mathrm{C}$.

\section{Specimen nomenclature}

Specimens were originally assigned names based on sampling location and order (Table 1).

\section{DNA extraction, PCR Amplification, and sequencing}

DNA was extracted from specimen portions (tentacles and column) weighing 5-20 mg using a spin-column Dneasy Animal Extraction protocol (Qiagen, Santa Clarita, CA, USA). PCR amplification using the genomic DNA as a template was performed using HotStarTaq DNA polymerase (QIAGEN, Tokyo, Japan) according to the manufacturer's instructions. Mitochondrial (mt) 16S rDNA was amplified following procedures outlined in Sinniger et al. (2005). COI was amplified using zoanthid-specific primer COIZoanF (Reimer et al., 2007a) and general COI primer HCO2198 (Folmer et al., 1994). PCR amplification was performed on the samples under the following conditions: an initial denaturing step at $95^{\circ} \mathrm{C}$ for 15 minute, followed by 35 cycles of 1 minute denature at $94^{\circ} \mathrm{C}, 1$ minute annealing at $40^{\circ} \mathrm{C}$, and $90 \mathrm{~s}$ extension at $72^{\circ} \mathrm{C}$, followed by 7 minutes' extension at $72^{\circ} \mathrm{C}$. The ITS-rDNA region of Symbiodinium was amplified following procedures outlined in Reimer et al. (2006c). The amplified products were visualized by $1.0 \%$ agar- ose gel electrophoresis. PCR products were treated with Exonuclease I and Alkaline Phosphatate (Shrimp) (Takara) prior to sequencing reactions using DTCS Quick Start Master Mix (Beckman Coulter). The products were analyzed using a CEQ8800 (Beckman Coulter) automated DNA sequencing system.

\section{Phylogenetic analyses}

New sequences obtained in the present study were deposited in GenBank (accession numbers HM130463HM130514). Nucleotide sequences of mt 16S rDNA and COI from samples were manually aligned with previously published $\mathrm{mt} 16 \mathrm{~S}$ rDNA and COI sequences from various zoanthid species representing the genera Palythoa, Zoanthus, Acrozoanthus, Isaurus, Parazoanthus, Antipathozoanthus, Savalia, Corallizoanthus, Hydrozoanthus, and Terrazoanthus. Originally, outgroup sequences for both mt $16 \mathrm{~S}$ rDNA and COI trees were from the genus Epizoanthus, and once the monophyly of the remaining zoanthids was confirmed, final phylogenetic trees were made without Epizoanthus outgroups to improve resolution.

For Symbiodinium ITS-rDNA sequences, different Symbiodinium clade sequences are highly divergent from each other, and an alignment of ITS-rDNA was downloaded from the Scott Santos laboratory homepage (http://www.auburn.edu/ santosr/), and new sequences from other recent studies were added. This alignment consisted of mainly the second internal ribosomal spacer of ribosomal DNA (ITS2), which has been shown to have great utility in identifying Symbiodinium types (e.g. LaJeunesse, 2002). GenBank Accession Numbers of Symbiodinium sequences used are given in the resulting phylogenetic tree.

All alignments were inspected by eye and manually edited. All ambiguous sites of the alignments were removed from the dataset for phylogenetic analyses. Consequently, four alignment datasets were generated: 1) 651 sites of 42 sequences (mt $16 \mathrm{~S}$ rDNA); 2) 300 sites of 49 sequences (COI); and 3) 336 sites of 59 sequences (Symbiodinium ITS-2). The alignment data are available on request from the corresponding author and at the homepage http://web.me.com/miseryukyu/.

For the phylogenetic analyses of the three alignments, the same methods were applied independently. Alignments were subjected to analyses with the maximum-likelihood (ML) with PhyML (Guindon and Gascuel, 2003) and neighbour-joining (NJ) methods. PhyML was performed using an input tree generated by BIONJ with the general time-reversible model (Ro- 


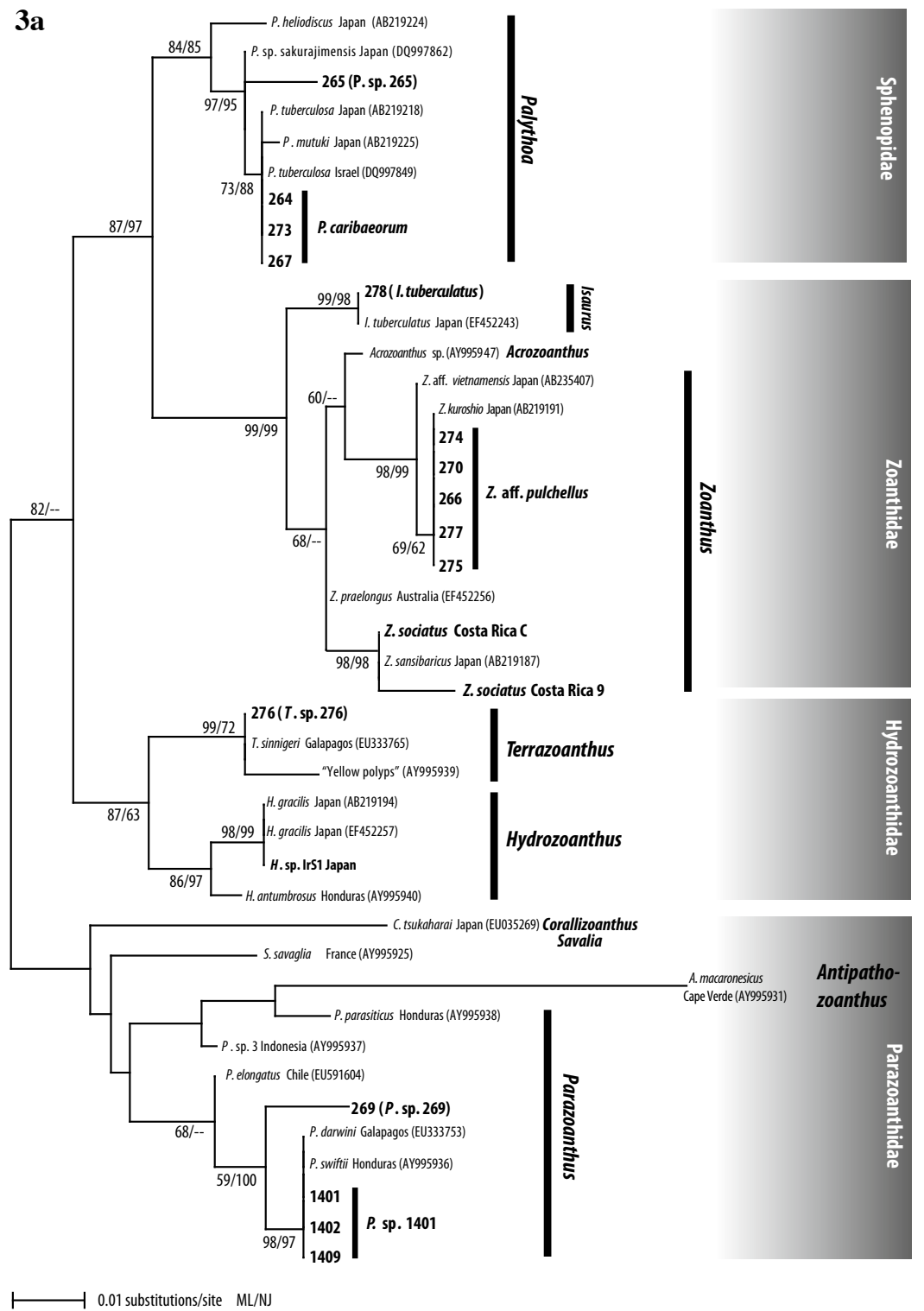

driguez et al., 1990) of nucleotide substitution incorporating invariable sites and a discrete gamma distribution (eight categories) $(\mathrm{GTR}+\mathrm{I}+\mathrm{G})$. The proportion of invariable sites, a discrete gamma distribution, and base frequencies of the model were estimated from the dataset. PhyML bootstrap trees (500 replicates) were constructed using the same parameters as the individual ML tree. The distances were calculated using a Kimura's 2-parameter model (Kimura, 1980). Support for NJ branches was tested by bootstrap analysis (Felsenstein, 1985) of 1000 replicates. PAUP* version 4.0 was used for phylogenetic analyses (Swofford, 1998).

\section{Results}

In situ morphological zoanthid identification

The preliminary in situ identifications of the zoanthid specimens are summarized in Table 1, and images of all species shown in Fig. 2. Specimens 264, 267 and 273 were seen to be sand-encrusting Palythoa forms (=immersae, Pax 1910) with an extremely well developed coenenchyme, and thus likely $P$. caribaeorum (Fig. 2a). Specimens 265 and 1425 were also sand-encrusted, and 'intermediae' (Pax, 1910) in colony and 


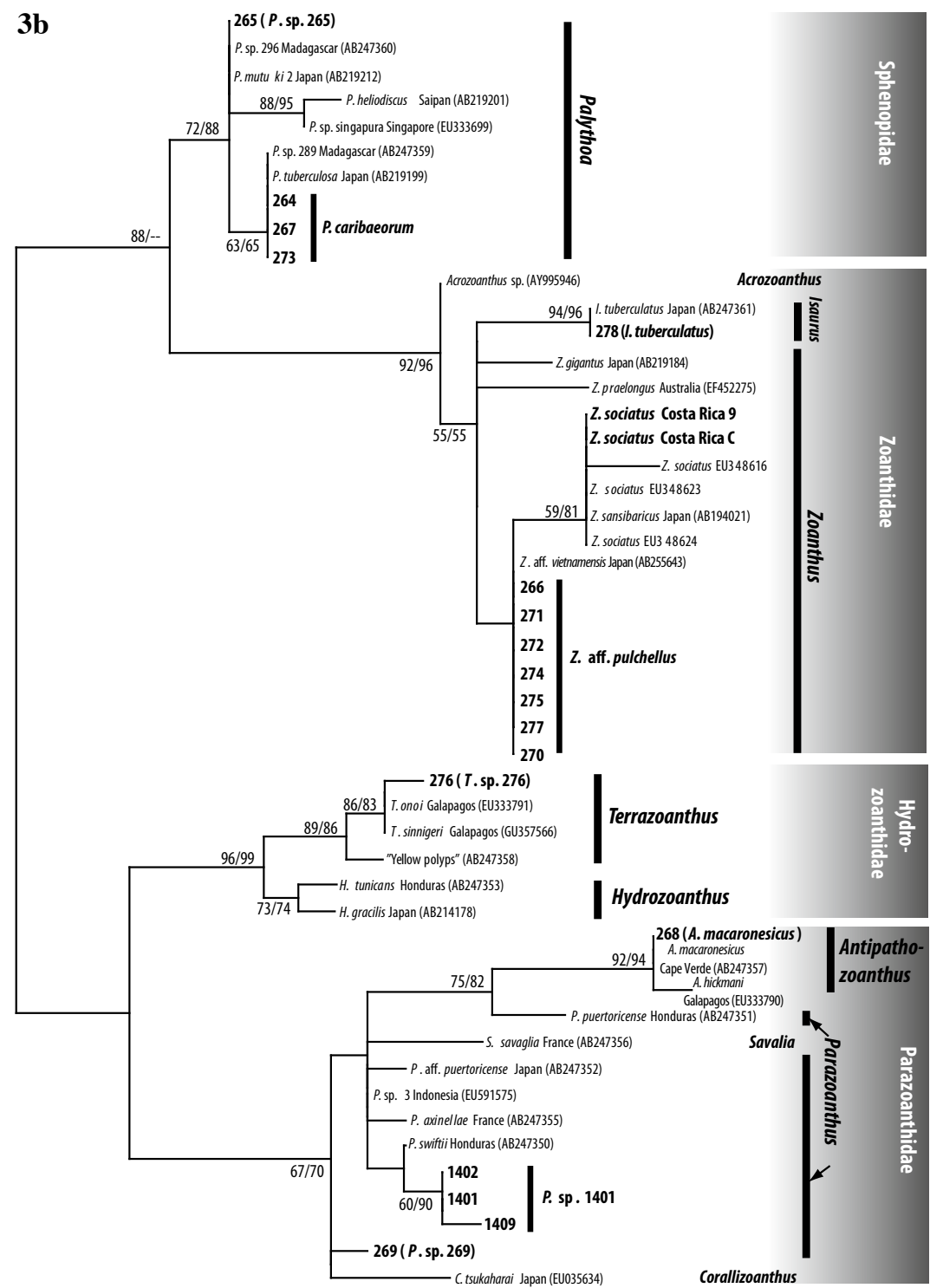

Fig. 3. Maximum likelihood (ML) trees of a) mitochondrial $16 \mathrm{~S}$ ribosomal DNA, and b) cytochrome oxidase subunit I (COI) sequences for zoanthid specimens. Values at branches represent ML and neighbor-joining (NJ) probabilities (>50\%), respectively. Sequences newly obtained in this study in bold. Sequences/species names from previous studies in regular font with GenBank Accession Numbers. For specimen information see Table 1 . polyp form, with approximately 60 relatively short tentacles (Fig. 2b). The oral disk patterning was purplebrown with white markings in primarily ring patterns, and septae were visible. This specimen did not match conclusively with any described Atlantic Palythoa species.

Several specimens were clearly members of the genus Zoanthus, and easily identifiable to genus level by the lack of sand encrustation and the smooth outer surfaces of polyps. Polyps were generally crowded together, and appeared to be 'immersae' or 'intermediae', growing from a well-developed coenenchyme (Fig. 2c). Tentacles numbered 50-64, and were all approximately half the length of the oral disk diameter. Most specimens examined were intertidal, and oral disk color varied widely from mint green (266), fluorescent green (270), dark purple with a fluorescent green oral opening (275), to pale pink (277). These Zoanthus specimens (also including specimen 1419) could not be conclusively identified to species level.

Specimens 278, 1406, and 1407 were clearly an Isaurus species due to the relatively large size of the polyps, a lack of sand encrustation and external tubercules on the polyps' outer surface, and following Muirhead and 
Ryland (1985) and Wirtz and Debelius (2003) the specimens were identified as Isaurus tuberculatus (Fig. 2d).

Specimen 268 was sand-encrusted, and found on the antipatharian Tanacetipathes cavernicola Opresko, 2001, and therefore preliminarily identified as Antipathozoanthus macaronesicus (Ocaña and Brito 2003; Ocaña et al., 2007; Sinniger et al., 2010) (Fig. 2e).

Specimen 269 (Fig. 2f) was also sand-encrusted but found associated with a sponge inside a cave; it was not identifiable to species level, although it was assigned to the revised genus Parazoanthus (Sinniger et al., 2010) based on this association. Specimens 1414 and 1424 were also assigned to this species.

Similarly, specimens 1401, 1402, and 1409 were found only in the vicinity of Tarrafal, generally in either dark (tunnel) or overhang locations, often but not always associated with either an orangish-red or yellow encrusting sponge (Fig. 2g). Again, based on the association with the sponge, it was assigned to the genus Parazoanthus.

Found during low tide on the underside of a large intertidal rock, the small sand-encrusted specimen 276 did not match with any known Atlantic zoanthid genus (Fig. 2h). Specimen 276 did, however, match in ecology to both undescribed zoanthids from the Pacific (Reimer et al., 2008c) and to one species of the newly described genus Terrazoanthus (Hydrozoanthidae), namely T. sinnigeri Reimer and Fujii, 2010. Due to this uncertainty, this specimen could not be identified even to family with initial examinations.

\section{DNA sequence and phylogenetic identification - $m t$ $16 S r D N A$}

Mitochondrial 16S ribosomal DNA (mt 16S rDNA) phylogenetic results are shown in Fig. 3a. The phylogenetic tree from analyses was similar in topology to previous studies examining Zoantharia, with most families forming well-supported clades. The very strongly supported clade of the family Zoanthidae $(\mathrm{ML}=99 \%, \mathrm{NJ}=99 \%)$ was seen to include identical sequences from specimens 266, 280, 274, 275, and 277 along with other Zoanthus, Acrozoanthus, and Isaurus sequences. Additionally, sequences from specimens 271 and 272 were identical to these sequences but shorter in length and were subsequently not used in phylogenetic analyses. These sequences were identical to sequence AB219191 from Zoanthus kuroshio Reimer and Ono, 2006 (in Reimer et al., 2006a), which together with AB235407 from Zoanthus aff. vietnamensis Pax and Muller, 1957 formed a strongly supported group (ML=98\%, NJ=99\%). Specimen 278 formed a separate monophyly with Isaurus tuberculatus from Japan (IKO1) (ML=99\%, NJ=98\%).

Sphenopidae sequences formed a moderately well supported clade (ML $=84 \%, \mathrm{NJ}=85 \%)$ and included sequences from specimens 264, 267, 273 and 265. The first three specimens' sequences were identical to Palythoa tuberculosa Klunzinger, 1877 sequences (AB219218, DQ997849) from Japan and Israel, and together with Palythoa mutuki Haddon and Shackleton, 1891 (AB219225) formed a moderately well supported monophyly (ML=73\%, $\mathrm{NJ}=88 \%$ ). This subclade was sister to another group that included 265 and Palythoa sp. sakurajimensis, and these together formed a monophyly ( $\mathrm{ML}=97 \%, \mathrm{NJ}=95 \%)$ separate from Palythoa heliodiscus Ryland and Lancaster, 2003.

Specimens 269, 1401, 1402, and 1409 were within a moderately supported Parazoanthidae clade $(\mathrm{ML}=68 \%, \mathrm{NJ}=<50 \%)$, and the latter three were part of a very well supported subclade (ML=98\%, $\mathrm{NJ}=97 \%$ ) including $P$. darwini Reimer and Fujii, 2010, and P. swiftii Duchassaing and Michelotti, 1860. The sequence from specimen 268 was too short to be included in the final phylogenetic analyses (approximately 400 bp in length), but was identical to a sequence from Antipathozoanthus macaronesicus (AY995930) previously collected from the Cape Verde Islands.

Specimen 276 was included in a monophyly ( $\mathrm{ML}=87 \%, \mathrm{NJ}=63 \%)$ of Hydrozoanthidae sequences, within a well-supported clade (ML=99\%, $\mathrm{NJ}=72 \%)$ that was sister to another clade containing Hydrozoanthus sequences ( $\mathrm{ML}=86 \%, \mathrm{NJ}=97 \%) .276$ was seen to be identical to a sequence obtained from Terrazoanthus onoi Reimer and Fujii, 2010 (EU333760) from the Galapagos Islands.

\section{COI}

Cytochrome oxidase subunit I (COI) phylogenetic results are shown in Fig. 3b. As seen with mt 16S rDNA results, the phylogenetic tree from analyses was similar in topology to previous studies examining Zoantharia, with each family forming a well-supported clade. The clade of the family Zoanthidae (ML=92\%, $\mathrm{NJ}=96 \%$ ) was seen to contain sequences from the largest number of specimens in this study. Sequences from specimens 266, 270, 271-275, and 277 were identical, and were also identical to GenBank sequence 
AB255643 (Zoanthus aff. vietnamensis, Japan) and also EU348616 ('Z Z. sociatus' Ellis and Solander, 1786, Brazil), which together formed a group $(\mathrm{ML}=<50 \%, \mathrm{NJ}=<50 \%)$ that was basal to another clade, containing other ' $Z$. sociatus', and Z $Z$. sansibaricus Carlgren, 1900 sequences ((ML=59\%, $\mathrm{NJ}=81 \%$ ). Specimen 278 formed a separate monophyly with Isaurus tuberculatus from Japan (IKO1) (ML $=94 \%, \mathrm{NJ}=96 \%$ ).

Sphenopidae sequences formed another group ( $\mathrm{ML}=72 \%, \mathrm{NJ}=88 \%)$. Within this family, sequences from 264, 267, and 273 were seen to be identical to sequences from Palythoa tuberculosa (AB219199), and these sequences formed a moderately supported monophyly $(\mathrm{ML}=63 \%, \mathrm{NJ}=65 \%)$. The $\mathrm{COI}$ sequence from 265 was identical to sequences from $P$. mutuki (AB219211), and these sequences were basal to the $P$. tuberculosa and related specimens and $P$. heliodiscus and related specimens' clades.

Specimen 269 was placed with the moderately well supported Parazoanthidae clade (ML=67\%, NJ=70\%), although resolution and bootstrap support within Parazoanthidae was not strong. Sequences from specimens 1401, 402, and 1409 formed a subclade $(\mathrm{ML}=60 \%, \mathrm{NJ}=90 \%)$ also within Parazoanthidae, derived from $P$. swiftii. Additionally, the COI sequence from specimen 268 was seen to be identical to a sequence from Antipathozoanthus macaronesicus from the Cape Verde Islands (AB247357), and together with A. hickmani Reimer and Fujii, 2010 (EU333790), formed a highly supported Antipathozoanthus subclade $(\mathrm{ML}=92 \%, \mathrm{NJ}=94 \%)$.

The COI sequence from specimen 276 was placed within a well-supported Hydrozoanthidae clade $(\mathrm{ML}=96 \%, \mathrm{NJ}=99 \%)$. Within Hydrozoanthidae, specimen 276 was most closely related to Terrazoanthus onoi (EU333791) and T. sinnigeri (GU357566) from the Galapagos Islands, forming a well-supported subclade ( $\mathrm{ML}=86 \%, \mathrm{NJ}=83 \%)$. Together with a sequence from Terrazoanthus sp. 'yellow polyps', these sequences formed a well-supported Terrazoanthus generic clade $(\mathrm{ML}=89 \%, \mathrm{NJ}=86 \%)$ separate from a $\mathrm{Hy}$ drozoanthus clade.

\section{Symbiodinium ITS-rDNA}

Internal transcribed spacer 2 (ITS2) phylogenetic results are shown in Fig. 4. Resulting ITS-2 sequence data were clear in both forward and reverse directions with no 'double-peaks', and thus no cloning was performed. Symbiodinium ITS2 sequences from speci- mens in this study were found to belong to three different Symbiodinium clades. Six of seven $Z$. aff. pulchellus colonies $(266,270,271,272,274,275)$ were found to contain clade A Symbiodinium, identical to the previously reported sequence AF427465 from Aiptasia anemones in Florida. These sequences, together with three novel sequences from Symbiodinium of two Z. sociatus colonies from Caribbean Costa Rica, formed a well-supported monophyly ( $\mathrm{ML}=98 \%$, $\mathrm{NJ}=90 \%$ ).

The remaining Z. aff. pulchellus colony Symbiodinium ITS2 sequence was from specimen 277 and grouped with two other ITS2 sequences that belonged to clade B, EU074874 from culture and AF195152 from Aiptasia anemones in Bermuda in a well-supported monophyly (ML=95\%, NJ=94\%) within the clade B lineage.

Symbiodinium ITS2 sequences from Palythoa (specimens 265, 267, and 273) and Isaurus (278) were unambiguously placed within clade $\mathrm{C}(\mathrm{ML}=72 \%$, $\mathrm{NJ}=73 \%$ ), within a large group that included many subclades of $\mathrm{C}$ previously observed in a variety of hosts, including isolates from Zoanthus, Isaurus, and Palythoa spp. from Japan.

\section{Discussion}

\section{Suborder Brachycnemina}

The results of this report are similar to recent studies conducted in the Galapagos Islands, another relatively isolated oceanic region, demonstrating the widespread distribution of some brachycnemic species (families Sphenopidae, Zoanthidae) (Reimer and Hickman, 2009), and the presence of potentially undescribed species within the families Parazoanthidae and Hydrozoanthidae in the suborder Macrocnemina (Reimer et al., 2008c; Reimer and Fujii, 2010).

In our study, most specimens of both Palythoa and Zoanthus appear to belong to species commonly found in the Caribbean. Specimens 264, 267, and 273 are assigned to Palythoa caribaeorum, as they are identical in ecology, morphology, and phylogenetics to previously examined specimens. It has previously been theorized that much of the Cape Verde Islands' coral fauna arrived from the Caribbean during the midPleistocene (Boekschoten and Best, 1988), and our results support this. These zoanthid specimens (along with specimen 265) also contained 'generalist' clade C Symbiodinium, as previously seen in Palythoa spp. in 


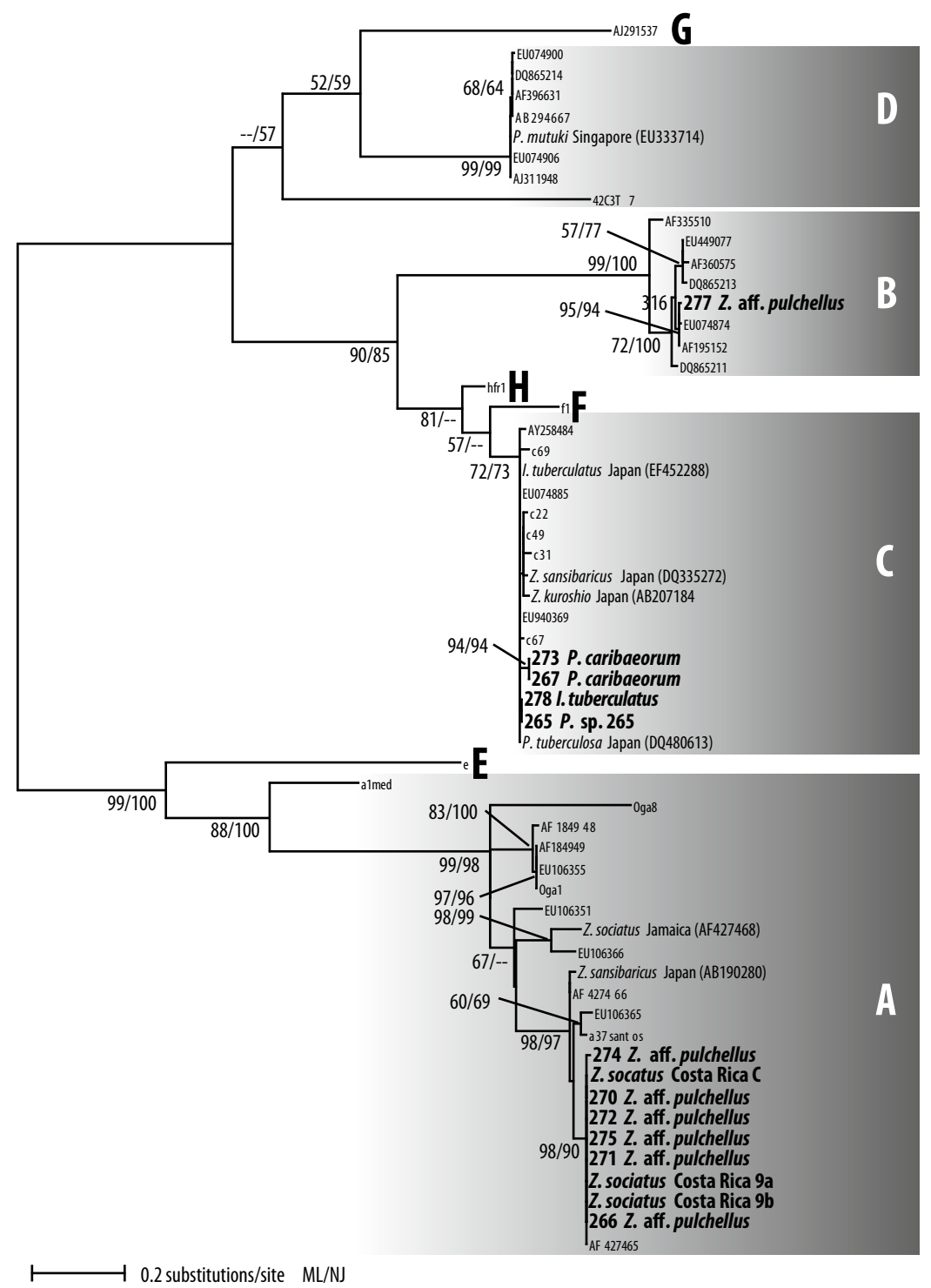

Fig. 4. Maximum likelihood tree of the internal transcribed spacer of ribosomal DNA (ITS-rDNA) sequences for Symbiodinium including specimens from this study. Values at branches represent ML and NJ bootstrap probabilities, respectively. New isolates and sequences from this study in bold, with host species and specimen number. Sequences/species names from previous studies in regular font with GenBank Accession Numbers, zoanthid-associated isolates from previous studies with species name and location, as well as GenBank Accession Number. Symbiodinium clades confirmed to be in symbiosis with zoanthid species (this study and previous studies) designated with shaded boxes. For specimen information see Table 1 . the northwestern Pacific (Reimer et al., 2006b).

Carlgren (1939) described a single Palythoa specimen from Sao Vincente Island as $P$. vincentina but given the large amount of morphological variation observed within Palythoa species (Burnett et al., 1997; Reimer et al., 2007c) we agree with the other previous reports of Palythoa in the Cape Verde Islands (Morri and Bianchi, 1995; Morri et al., 2000; Monteiro et al., 2008) that this is most likely P. caribaeorum. Similarly, although both $P$. dartevellei and $P$. senegalensis have been described from West Africa (Pax, 1952; Pax and Müller, 1956, respectively), these species, for the same reasons as above, are likely to be $P$. caribaeorum.
Preliminary phylogenetic analyses of Palythoa from Senegal indicate specimens from this region are monophyletic with $P$. caribaeorum, and will be presented elsewhere (Reimer and Wirtz, unpublished data).

While it is clear specimen 265 belongs to the genus Palythoa, it is different in both morphology and DNA sequences from known Palythoa species, and may be an undescribed species. Although in outward appearance (color, tentacle length) it appears similar to an undescribed 'brown zoanthid' from the Caribbean in Humann (2002), specimen 265 was found in both shallow tidepools and at deeper $(9 \mathrm{~m})$ locations, unlike the 'brown zoanthid' found only at 6 to 18 meters. 
Additionally, DNA analyses did not match previously investigated Palythoa species, although there is a lack of sequences from Atlantic species. For now, the species identity of this single specimen remains elusive and we preliminarily designate this species as Palythoa sp. 265.

We did not observe $P$. variabilis in this study, which is known to be amphi-atlantic (Pax and Müller, 1956), and we expected to locate this species in the Cape Verde Islands during the course of this study. Further examinations may yet confirm $P$. variabilis in the Cape Verde Islands.

Zoanthus specimens 266, 270, 271, 272, 274, 275, and 277 all grouped closely with previously examined $Z$. aff. vietnamensis and Z. kuroshio specimens from Japan, and it is very likely all the Cape Verde Islands Zoanthus specimens belong to one Atlantic species closely related to the Pacific Z. aff. vietnamensis/Z. kuroshio group. While Zoanthus specimens here have been preliminarily assigned to the species group $Z$. aff. pulchellus, the phylogenetic results demonstrate problems with this identification, as specimens previously identified by zoanthid researchers as ' $Z$. sociatus' fall into both of the major Zoanthus clades (Fig. 3, additional data not shown). However, the Zoanthus sequences from the Cape Verde Islands very clearly did not match with $Z$. sociatus sequences from specimens collected by the first author from the Caribbean coast of Costa Rica (Fig. 3b). We tentatively identify these specimens as Z. aff. pulchellus, as they could also perhaps be Z. solanderi Lesueur, 1817 sensu Karlson (1980), although sketches of both species in Duerden (1898) show the Cape Verde Islands specimens fit most closely with Z. pulchellus. Zoanthus specimens from the Cape Verde Islands were found primarily in the intertidal zone, while both Z. pulchellus and Z. solanderi have been generally found in the subtidal zone (Karlson, 1980; Humann, 2002). Similar to previous studies (Burnett et al., 1997; Reimer et al., 2004), these results demonstrate the difficulty of proper species identification in the genus Zoanthus. These are the first Zoanthus spp. records documented from the Cape Verde Islands.

The majority of the Cape Verde Islands Zoanthus specimens here (six of seven) were shown to contain Symbiodinium from clade A, as were two Z. sociatus samples from Caribbean Costa Rica. Clade A has previously been found in zoanthids from Jamaica in the Caribbean, and from intertidal Z. sansibaricus specimens in southern Japan (Reimer et al., 2006c), and is speculated to be adapted to high levels of UV light (LaJeunesse, 2002). This theory fits well with the distribution of the specimens from the Cape Verde Is- lands in the intertidal zone. Additionally, Zoanthus species may offer less protection from UV light than both I. tuberculatus (thicker body walls) and the sandencrusted Palythoa species, which were not observed to contain clade A in the Cape Verde Islands.

Surprisingly, Zoanthus specimen 277 contained Symbiodinium most closely related to clade B, which has not previously been found in association with brachycnemic zoanthids ( $\mathrm{T}$. LaJeunesse, pers. comm.), despite numerous papers specifically examining the symbionts of Zoanthus and Palythoa spp. (Burnett, 2002; Reimer et al., 2006b, 2006c, 2007b; Reimer and Todd, 2009). As only a single colony containing clade B was found in this study, future Symbiodinium research in the Cape Verde Islands should examine Zoanthus spp. in more detail to more clearly understand how widespread clade B is within the zoanthid community.

The identification of Isaurus tuberculatus was relatively easy given the unique polyp shape of this genus, and the previous reference to this species in the Cape Verde Islands (Wirtz and Debelius, 2003). However, as Pacific and Atlantic zooxanthellate zoanthids have probably been separated since the closing of the Isthmus of Panama (Reimer et al., 2008a), this species may be split into Atlantic and Pacific sibling species in the future. Further research utilizing ITS-rDNA or other relatively fast-evolving DNA markers is needed to test this hypothesis. Similar to previous results from the Pacific (Reimer et al., 2008b), I. tuberculatus was seen to contain 'generalist' Symbiodinium belonging to clade C.

\section{Suborder Macrocnemina}

In this study we found only four species from the suborder Macrocnemina in the Cape Verde Islands, including Antipathozoanthus macaronesicus, which has already been well documented (Ocaña and Brito, 2003; Ocaña et al., 2007; Sinniger et al., 2010; as 'undescribed zoanthid from Cape Verde' in Sinniger et $a l ., 2005)$. It is likely that more macrocnemic species exist in the waters around the Cape Verde Islands given the rich marine environment.

The discovery of a species within the genus Terrazoanthus in the Cape Verde Islands (specimen 276) is notable in that this is the first record from the Atlantic for this newly created genus, making this genus circumtropical in distribution - both previous species were known from the Indo-Pacific. Terrazoanthus sp. 276 was found under rocks, similar to $T$. sinnigeri from the Galapagos. Although the polyps of this species are not particularly small for zoanthids, it may 
have a cryptic ecology similar to T. sinnigeri. In this study, only one colony was found at Murdeira Bay on Sal Island, and more specimens are needed to properly discuss this species and to formally describe it.

Morphology and DNA sequences from specimen 269 did not fit with any known zoanthid, although due to its association with sponges and phylogenetic placement, this specimen appears to be an undescribed Parazoanthus species, which here is called Parazoanthus sp. 269. Morphologically, this species appears divergent from most known Parazoanthus species, with relatively long and thin tentacles, and a very large oral disc diameter compared to the diameter at the base of the polyps. Similar to the Terrazoanthus species above, more specimens and in situ observation along with morphological analyses are needed to properly describe this species.

The fourth species recorded in this study was another Parazoanthus species, preliminarily designated Parazoanthus sp. 1401. This species was phylogenetically very closely related to both Parazoanthus swiftii and Parazoanthus darwini. However, morphologically it is very different from $P$. darwini, with polyps quite clear from the coenenchyme, unlike $P$. darwini. Additionally, in coloration (pale yellow opposed to pink or orange for $P$. darwini) tentacle number (approximately 24 tentacles, opposed to 24-30 for $P$. darwini), and distribution (Cape Verde Islands as opposed to the Galapagos Islands) these specimens are different and clearly not $P$. darwini. Morphologically, these specimens do resemble $P$. swiftii with regards to tentacle number (sen$s u$ Swain, 2009) and polyp shape, but $P$. swiftii is currently known only from the Caribbean, and as COI sequences are also different between these two species, it is likely Parazoanthus sp. 1401 is an undescribed species (Sinniger et al., 2008). One possible future method to further ascertain this would be to examine the fasterevolving ITS-rDNA, as performed in Reimer and Fujii (2010).

Historically, there is a single zoanthid record, of a species designated Thoracactis topsenti Gravier, 1918, commensal on a sponge found at 800-1100 off the Cape Verde Islands. This species, the only representative of its genus, is currently placed within the family Epizoanthidae. Gravier (1918) thought that this species was a 'zoanthid-like actinian', although its presence on sponges, two rows of tentacles, bright yellow color, and encrustation all strongly suggest this is a zoanthid, not of the family Epizoanthidae but more likely from the family Parazoanthidae.

Despite the low number of brachycnemic zoanthid specimens in this study, it is clear the Cape Verde Is- lands harbor undescribed, possibly endemic species. Future investigations should help understand the true levels of brachycnemic zoanthid diversity in these islands, and will likely lead to the discovery of more undescribed species.

\section{Conclusions}

The Cape Verde Islands are home to at least eight species of zoanthids, four of them zooxanthellate brachycnemic zoanthids. These zooxanthellate zoanthids are for the large part in symbioses with clades of Symbiodinium that have previously been recorded in association with zoanthids (Clades A and C). However, one colony of $Z$. aff. pulchellus was found to contain clade B Symbiodinium, a first for zoanthids. These results indicate a need for further, more in-depth investigations into Symbiodinium diversity in the Cape Verde Islands and surrounding areas. Furthermore, it appears that there may be undiscovered zoanthid diversity, as currently at least two undescribed species exist in the waters of the Cape Verde Islands, Terrazoanthus sp. 276 and Parazoanthus sp. 269, and likely two additional species, Palythoa sp. 265 and Parazoanthus sp. 1401.

\section{Acknowledgements}

Emanuel d'Oliveira and Georg Bachschmid of the King Bay Diving Centre at Tarrafal/Santiago Island and Nuno Marques da Silva of the Manta Diving Centre at Santa Maria/Sal Island were of immeasurable help during field work. Mr. d'Oliveira also collected the Isaurus specimen in this study. Drs. H. Zibrowius and D. Fautin helped in the search for historical records of zoanthids from the Cape Verde Islands. The Centro de Ciências do Mar (CCMAR) of the University of the Algarve partly financed three trips to the Cape Verde Islands by P.W. Dr. Todd LaJeunesse (Pennsylvania State University) is thanked for his advice regarding Symbiodinium. J.D.R. was supported in part by the Rising Star Program at the University of the Ryukyus, and a grant-in-aid ('Wakate B') from the Japan Society for the Promotion of Science. Two anonymous reviewers comments greatly improved this manuscript.

\section{References}

Boekschoten GJ, Borel Best M. 1988. Fossil and recent shallow water corals from the Atlantic islands off Western Africa. Zoologische Mededelingen, Leiden 62: 99-112.

Brito A, Herrera R, Falcón JM, García-Charton JA, Barquín J, Pérez-Ruzafa A. 1999. Contribución al conocimiento de la ictiofauna de las islas de Cabo Verde. Revista de la Academia Canaria de Ciencias 11: 27-41.

Burnett WJ. 2002. Longitudinal variation in algal symbionts 
(zooxanthellae) from the Indian Ocean zoanthid Palythoa caesia. Marine Ecology Progress Series 234: 105-109.

Burnett WJ, Benzie JAH, Beardmore JA, Ryland JS. 1997. Zoanthids (Anthozoa, Hexacorallia) from the Great Barrier Reef and Torres Strait, Australia: systematics, evolution and a key to species. Coral Reefs 16: 55-68.

Carlgren O. 1939. Actiniaria and Zoantharia of the Scottish National Antarctic Expedition, 1902-1904. Transactions of the Royal Society of Edinburgh 49: 791-800.

Den Hartog JC, Holthuis LB. 1984. A note on an interesting association of the crab Platypodiella picta (A. Milne Edwards 1869) and species of Zoantharia. Courier Forschungsinstitut Senckenberg 68: 21-29.

Den Hartog JC, Türkay T. 1991. Platypodiella georgei spec. nov. (Brachyura: Xanthidae), a new crab from the island of St. Helena, South Atlantic Ocean, with notes on the genus Platypodiella Guinot, 1967. Zoologische Mededelingen, Leiden 65: 209-220.

Duchassaing P, Michelotti G. 1860. Mémoire sur les Coralliaires des Antilles. Turin: Imprimerie Royale.

Duchassaing P, Michelotti G. 1864. Supplément au mémoire sur les Coralliaires des Antilles. Turin: Imprimerie Royale.

Duerden JE. 1898. Jamaican Actiniaria. Part I. - Zoantheae. Scientific Transactions of the Royal Dublin Society 6: 329385.

Ellis J, Solander D. 1786. The Natural History of Many Curious and Uncommon Zoophytes, Collected from Various Parts of the Globe. London: Benjamin White and Son.

Felsenstein J. 1985. Confidence limits on phylogenies: an approach using the bootstrap. Evolution 39: 783-791.

Folmer O, Black M, Hoeh W, Lutz R, Vrijenhoek R. 1994. DNA primers for amplification of mitochondrial cytochrome $\mathrm{c}$ oxidase subunit I from diverse metazoan invertebrates. Molecular Marine Biology and Biotechnology 3: 294-299.

Freitas R, Castro M. 2005. Occurrence of Panulirus argus (latreille,1804) (Decapoda, Palinuridae) in the northwest Islands of the Cape Verde archipelago (central-east Atlantic). Crustaceana 78: 1191-1201.

Gravier C. 1918. Note sur une actinie (* Thoracactis* n. g., *topsenti* $\mathrm{n}$. sp.) et un annélide polychète (* Hermadion Fauveli* $^{*}$ n. sp.), commensaux d'une éponge siliceuse (* Sarostegia oculata* Topsent). Bulletin de l'Institut Océanographique (Monaco) 344: 1-20.

Guindon S, Gascuel O. 2003. A simple, fast, and accurate algorithm to estimate large phylogenies by maximum likelihood. Systematic Biology 52: 696-704.

Haddon AC, Shackleton AM. 1891. Reports on the zoological collections made in Torres Straits by Professor A.C. Haddon, 1888-1889. Actiniæ: I. Zoantheæ. Scientific Transactions of the Royal Dublin Society 4: 673-701.

Humann P. 2002. Reef creature identification (Florida Caribbean Bahamas). Jacksonville: New World Publications.

Karlson RH. 1980. Alternative competitive strategies in a periodically disturbed habitat. Bulletin of Marine Science 30: 894-900.

Kimura M. 1980. A simple method for estimating evolutionary rates of base substitutions through comparative studies of nucleotide sequences. Journal of Molecular Evolution 16: 111-120.

Klunzinger CB. 1877. Die Korallthiere des Rothen Meeres. 1: Die Alcyonarien und Malacodermen. Berlin: Gutmann'schen Buchhandlung.
Laborel J. 1974. West African reef corals: an hypothesis on their origin. Proceedings of the Second International Coral Reef Symposium 1: 425-443.

LaJeunesse TC. 2002. Diversity and community structure of symbiotic dinoflagellates from Caribbean coral reefs. $M a$ rine Biology 141: 387-400.

Lesueur CA. 1817. Observations on several species of the genus Actinia, illustrated by figures. Journal of the Academy of Natural Sciences of Philadelphia. 1: 149-154, 169-189.

Monteiro J, Almeida C, Freitas R, Delgado A, Porteiro F, Santos RS. 2008. Coral assemblages of Cabo Verde: preliminary assessment and description. Proceedings of the $11^{\text {th }}$ International Coral Reef Symposium: 1416-1419.

Morri C, Bianchi CN. 1995. Cnidarian zonation at Ilha do Sal (Arquipelago de Cabo Verde). Beitrage zur Palaeontologie 20: $41-49$.

Morri CR, Cattaeno-Vietti R, Sartori G, Bianchi CN. 2000. Shallow epibenthic communities of Ilha do Sal (Cape Verde Archipelago, eastern Atlantic). Aquipélago Life and Marine Sciences, Suppl. 2 (Part A): 157-165.

Muirhead A, Ryland JS. 1985. A review of the genus Isaurus Gray 1828 (Zoanthidea), including new records from Fiji. Journal of Natural History 19: 323-335.

Núñez J, Viera G, Riera R, Brito MC. 2000. Anélidos poliquetos bentónicos de las islas de Cabo Verde: primer catálogo faunístico. Revista de la Academia Canaria de Ciencias 11: 135-172.

Ocaña O, Brito A. 2003. A review of Gerardiidae (Anthozoa: Zoantharia) from the Macaronesican islands and the Mediterranean Sea with the description of a new species. Revista de la Academia Canaria de Ciencias 15: 159-189.

Ocaña O, Brito A, Gonzalez G, Herrera R. 2007. Additions in relation to Gerardiidae from the Macaronesican waters and the Mediterrenean Sea (Anthozoa: Zoantharia). Vieraea 35: 163-168.

Opresko DM. 2001. New species of antipatharians (Cnidaria: Anthozoa) from Madeira, with the establishment of a new genus. Proceedings of the Biological Society of Washington 114: 349-358.

Opresko DM. 2003. A new species of Allopathes (Cnidaria: Antipatharia) from the eastern Atlantic. Zoologische Verhandelingen, Leiden 345: 275-280.

Pax F. 1910. Studien an westindischen Actinien. Zoologische Jahrbücher Suppl. 11: 157-330.

Pax F. 1952. Die Krustenanemonen des Tropischen Westafrikas. Annales du Musée Royal du Congo Belge. Sciences Zoologiques 15: 7-81.

Pax F, Müller I. 1956. Zoantharien aus Französisch Westafrika. Bulletin de l'Institut Fondamental de l'Afrique Noire 18: 418-458.

Pax F, Müller I. 1957. Zoantharien aus Viet-Nam. Memoires du Museum National d' Histoire Naturelle, Paris 16: 1-40.

Prud'homme van Reine W, van den Hoek C. 1988. Biogeography of Capeverdean seaweeds. Courier Forschungsinstitut Senckenberg 105: 35-49.

Reimer JD, Ono S, Fujiwara Y, Takishita K, Tsukahara J. 2004. Reconsidering Zoanthus spp. diversity: molecular evidence of conspecificity within four previously presumed species. Zoological Science 21: 517-525.

Reimer JD, Ono S, Iwama A, Tsukahara J, Takishita K, Maruyama T. 2006a. Morphological and molecular revision of 
Zoanthus (Anthozoa: Hexacorallia) from southwestern Japan with description of two new species. Zoological Science 23: 261-275.

Reimer JD, Takishita K, Maruyama T. 2006b. Molecular identification of symbiotic dinoflagellates (Symbiodinium spp.) from Palythoa spp. (Anthozoa: Hexacorallia) in Japan. Coral Reefs 25: 521-527.

Reimer JD, Takishita K, Ono S, Maruyama T, Tsukahara J. 2006c. Latitudinal and intracolony ITS-rDNA sequence variation in the symbiotic dinoflagellate genus Symbiodinium (Dinophyceae) in Zoanthus sansibaricus (Anthozoa: Hexacorallia). Phycological Research 54: 122-132.

Reimer JD. 2007. Preliminary survey of zooxanthellate zoanthid diversity (Hexacorallia: Zoantharia) from southern Shikoku, Japan. Kuroshio Biosphere 3: 1-16, 7 pls.

Reimer JD, Hirano S, Fujiwara Y, Sinniger F, Maruyama T. 2007a. Morphological and molecular characterization of Abyssoanthus nankaiensis, a new family, new genus and new species of deep-sea zoanthid (Anthozoa: Hexacorallia: Zoantharia) from a northwest Pacific methane cold seep. Invertebrate Systematics 21: 255-262.

Reimer JD, Ono S, Tsukahara J, Takishita K, Maruyama T. 2007b. Non-seasonal clade-specificity and subclade microvariation in symbiotic dinoflagellates (Symbiodinium spp.) in Zoanthus sansibaricus (Anthozoa: Hexacorallia) at Kagoshima Bay, Japan. Phycological Research 55: 58-65.

Reimer JD, Takishita K, Ono S, Maruyama T. 2007c. Diversity and evolution in the zoanthid genus Palythoa (Cnidaria: Hexacorallia) utilizing nuclear ITS-rDNA. Coral Reefs 26 : 399-410.

Reimer JD, Ono S, Sinniger F, Tsukahara J. 2008a. Distribution of zooxanthellate zoanthid species (Zoantharia: Anthozoa: Hexacorallia) in southern Japan limited by cold temperatures. Galaxea JCRS 10: 57-67.

Reimer JD, Ono S, Tsukahara J, Iwase F. 2008b. Molecular characterization of the zoanthid genus Isaurus (Anthozoa: Hexacorallia) and its zooxanthellae (Symbiodinium spp). Marine Biology 153: 351-363.

Reimer JD, Sinniger F, Hickman CP Jr. 2008c. Zoanthid diversity (Anthozoa: Hexacorallia) in the Galapagos Islands: a molecular examination. Coral Reefs 27: 641-654.

Reimer JD, Hickman CP Jr. 2009. Preliminary survey of zooxanthellate zoanthids (Cnidaria: Hexacorallia) of the Galápagos and associated symbiotic dinoflagellates (Symbiodinium spp.). Galápagos Research 66: 14-19.

Reimer JD, Todd PA. 2009. Preliminary molecular examination of zooxanthellate zoanthids (Hexacorallia: Zoantharia) and associated zooxanthellae (Symbiodinium spp.) diversity in Singapore. Raffles Bulletin of Zoology Suppl. 22: 103-120.

Reimer JD, Fujii T. 2010. Four new species and one new genus of zoanthids (Cnidaria: Hexacorallia) from the Galápagos. ZooKeys 42: 1-36.

Reimer JD, Nakachi S, Hirose M, Hirose E, Hashiguchi S. 2010. Using hydrofluoric acid for morphological investigations of zoanthids (Cnidaria: Anthozoa): a critical assessment of methodology and necessity. Marine Biotechnology 12: 605-617.
Reiner F. 1996. Catálogo dos Peixes do Arquipélago de Cabo Verde. Lisbon: IPIMAR.

Rolán E. 2005. Malacological Fauna from the Cape Verde Archipelago. Hackenheim: Conchbooks.

Rodriguez F, Oliver JL, Marin A, Medina JR. 1990. The general stochistic model of nucleotide substitution. Journal of Theoretical Biology 142: 485-501.

Ryland JS, Lancaster JE. 2003. Revision of methods for separating species of Protopalythoa (Hexacorallia: Zoanthidea) in the tropical West Pacific. Invertebrate Systematics 17: 407-428.

Sinniger F, Montoya-Burgos JI, Chevaldonnè P, Pawlowski J. 2005. Phylogeny of the order Zoantharia (Anthozoa, Hexacorallia) based on the mitochondrial ribosomal genes. $M a$ rine Biology 147: 1121-1128.

Sinniger F. 2006. Zoanthids of New Caledonia. Pp. 127-128 in: Payri C, Richier de Forges B, eds., Compendium of marine species from New Caledonia. Noumea: IRD Editions.

Sinniger F, Reimer JD, Pawlowski J. 2008. Potential of DNA sequences to identify zoanthids (Cnidaria: Zoantharia). Zoological Science 25: 1253-1260.

Sinniger F, Reimer JD, Pawlowski J. 2010. The Parazoanthidae DNA taxonomy: Description of two new genera. Marine Biodiversity 40: 57-70.

Stokvis FR, Ofwegen LP van. 2006. New and redescribed encrusting species of Alcyonium from the Atlantic Ocean (Octocorallia: Alcyonacea: Alcyoniidae). Zoologische Verhandelingen Leiden 80: 165-183.

Swain TD. 2009. Isozoanthus antumbrosus, a new species of zoanthid (Cnidaria: Anthozoa: Zoanthidea) symbiotic with Hydrozoa from the Caribbean, with a key to hydroid and sponge-symbiotic zoanthid species. Zootaxa 2051: 41-48.

Swofford DL. 1998. PAUP*. V Phylogenetic analysis using parsimony (*and other methods), version 4. Sunderland, MA: Sinauer Associates.

Türkay M. 1982. Marine Crustacea Decapoda von den Kapverdischen Inseln mit Bemerkungen zur Zoogeographie des Gebietes. Courier Forschungsinstitut Senckenberg 52: 91-129.

Van der Land J. 1993. Marine biota of the Cape Verde Islands. Courier Forschungsinstitut Senckenberg 159: 39-44.

Wirtz P. 2001. New records of marine invertebrates from the Cape Verde Islands. Arquipélago Life and Marine Sciences 18A: 81-84.

Wirtz P. 2009. Thirteen new records of marine invertebrates and two of fishes from Cape Verde Islands. Arquipélago Life and Marine Sciences 26: 51-56.

Wirtz P, Debelius H. 2003. Mediterranean and Atlantic invertebrate guide: from Spain to Turkey, from Norway to the equator. Hackenheim: Conchbooks.

Wirtz P, d'Udekem d'Acoz C. 2001. Decapod crustaceans associated with Antipatharia, Gorgonaria and Mollusca at the Cape Verde Islands. Helgoland Marine Research 55: 112115.

Received: 12 April 2010

Revised and accepted: 17 September 2010

Published online: 15 November 2010

Editor: R.W.M. van Soest 


\section{Appendix}

\section{Zoanthids of the Cape Verde Islands}

\section{Family Zoanthidae}

This is the only family of zoanthids that is not sandencrusted, and includes three zooxanthellate genera; Zoanthus, Isaurus, and Acrozoanthus. Found in shallow tropical and subtropical environments. All species have brachycnemic mesentery arrangement, with the $5^{\text {th }}$ mesentery from the dorsal directive imperfect.

\section{Zoanthus aff. pulchellus Duchassaing de Fom-} bressin and Michelotti, 1864; Fig. 2c

In the Cape Verde Islands, this species was found primarily in tidepools in the lower intertidal zone at both Santiago and Sal Islands. Colonies can be partly out of the water during low tide. Colonies can be quite large (e.g. up to hundreds or thousands of polyps), and completely cover the hard substrate (rock, dead coral) to which they are attached. Colonies edges can be 'tongue-like' in appearance. Polyps closely packed together, often crowding one another and giving each polyp a 'hexagonal' shape. Polyps are 'immersae' or 'intermediae' (Pax, 1910) in form, not totally extending free and clear of the well-developed coenenchyme. Oral disk colors include pale salmon pink, dark green, light green, and fluorescent green, with approximately 50 tentacles that are usually olive green or reddishbrown in color. Tentacle length usually less than oral disk diameter; oral disk diameters up to $10 \mathrm{~mm}$ when expanded, contracted polyps 3-6 $\mathrm{mm}$ in diameter. This species appears to be closely related to the Pacific $Z$. vietnamensis/Z. kuroshio species group.

\section{Isaurus tuberculatus Gray, 1828; Fig. 2d}

This species has so far only been found around Tarrafal, Santiago Island in the Cape Verde Islands, on rocky substrate, in deeper (at least $18 \mathrm{~m}$ ) waters. Colony color varied from light brown to green to bright red. The few colonies observed consisted of $<20$ polyps. Polyps have tubercules (bumps) on their outer surfaces, and this species is rarely observed with its oral disks open. Polyps up to $20-30 \mathrm{~mm}$ in length, connected at their base to reduced coenenchyme.

\section{Family Sphenopidae}

Similar to Zoanthidae this family is common in tropical and subtropical waters worldwide. Unlike Zoan- thidae, species of this family is generally very heavily encrusted with sand. This family consists of two genera, the zooxanthellate Palythoa and azooxanthellate, solitary Sphenopus, which has only a few species known from the Indo-Pacific. All species have brachycnemic mesentery arrangement, with the $5^{\text {th }}$ mesentery from the dorsal directive imperfect.

\section{Palythoa caribaeorum (Duchassaing and Mich- elotti, 1864); Fig. 2a}

This species is widespread throughout the Atlantic, from the Caribbean and Florida to southern Brazil, and along the west coast of Africa. In the Cape Verde Islands it has been found at both Santiago and Sal Islands (this study) and Sao Vincente Island (Carlgren, 1939). P. caribaeorum can be distinguished by its 'immersae' form, with tightly packed polyps embedded with a very well developed coenenchyme. This species is found from the intertidal to depths of approximately $20 \mathrm{~m}$ (Morri and Bianchi, 1995; Morri et al., 2000; Monteiro et al., 2008; this study) in the Cape Verde Islands, and similar to the closely related Pacific $P$. tuberculosa/P. caesia Dana, 1846, can often dominate the substrate, covering rock and dead coral with a large mat. Intertidal colonies may be completely out of the water during low tide. Edges of colonies often 'tonguelike' in appearance. Colonies may be very large $\left(>1 \mathrm{~m}^{2}\right)$. Although colony color depends much on the color of encrusted detritus, most colonies are usually brown, with some light fluorescent yellow and darker brown colonies present. Polyps up to $15 \mathrm{~mm}$ in diameter although usually smaller, with oral disk usually brown, tan, or white. Tentacle number may vary, but usually approximately 34-48. Tentacles usually quite short (e.g. < half oral disk diameter).

\section{Palythoa sp. 265; Fig. 2b}

This potentially undescribed species was observed only at Tarrafal, Santiago Island in the Cape Verde Islands. Although similar in appearance to the Pacific P. mutuki, this species is clearly molecularly a different species. Colonies are found in cracks of rocks in the low intertidal. One colony was found in $9 \mathrm{~m}$ depth in a shaded depression in a horizontal rock platform. Polyps are larger than Zoanthus species (contracted polyp diameter up to approximately $10 \mathrm{~mm}$ ), and extend free and clear of the well-developed basal coenenchyme ('liberae'). Oral disks up to $20 \mathrm{~mm}$ in diameter, usually smaller, and somewhat regularly 
spaced, with a less crowded appearance than both $P$. caribaeorum and $Z$. aff. pulchellus above. Observed colonies were small, with $<50$ polyps. As with $P$. caribaeorum above, encrustation color likely affects colony color; most colonies are dark brown in color, with oral disks dark brown with some lighter brown or gold patterns (flecks or small stripes), lighter towards the oral opening, with septae slightly visible. Capitular ridges prominent on closed polyps. Up to 64-68 short tentacles, which are brown or olive brown-gray.

\section{Family Parazoanthidae}

This family has been recently redefined (Sinniger et $a l ., 2010)$. Many species associated with hydrozoans, or present directly on rock or dead coral substrate (Reimer and Fujii, 2010) have been moved to the family Hydrozoanthidae. The redefined Parazoanthidae includes mostly zoanthids that are commensal on other marine invertebrates, including antipatharians, precious corals, and sponges. As currently defined, most species in this family can be assigned to a genus based on their substrates. All species have macrocnemic mesentery arrangement, with the $5^{\text {th }}$ mesentery from the dorsal directive perfect.

\section{Antipathozoanthus macaronesicus (Ocaña and} Brito, 2003); Fig. 2e

Originally described as Savalia macaronesica, this species has recently been re-assigned to a genus of zoanthids found exclusively on antipatharians (black corals), and is the type species of this new genus; Antipathozoanthus (Sinniger et al., 2010). Described from the Canary Islands and the Cape Verde Islands, in the Cape Verde Islands A. macaronesicus is usually found growing on antipatharians of the genus Tanacetipathes, and thus can be encountered only at deeper SCUBA depths or inside caves, where the antipatharian is present. In this study, A. macaronesicus was only found at Tarrafal, Santiago Island, but has previously been recorded from Sal Island as well (Ocaña and Brito, 2003). Polyps are spaced regularly, attached to a well-developed coenenchyme, and 3-6 $\mathrm{mm}$ in diameter, 4-15 $\mathrm{mm}$ in height. Expanded oral disks up to approximately $8-10 \mathrm{~mm}$ in diameter. Coenenchyme and the outer surface of polyps generally light pink, with oral disks brighter orange-pink. Light sand encrustations often clearly visible on the outside of polyps. Tentacles approximately 42 in number, and can be very long (up to twice oral disk diameter).

\section{Parazoanthus sp. 269; Fig. $2 \mathrm{f}$}

This species is currently known from only one area (Tarrafal, Santiago Island) in the Cape Verde Islands, where it was found on the rear walls of deep depressions in the rock face (i.e. in dim light) in about $20 \mathrm{~m}$ depth, occasionally associated with an encrusting sponge but often on rock or shell surfaces. Phylogenetically, Parazoanthus sp. 269 fits well within a Parazoanthus clade, although it does not match with any known Parazoanthus species. Polyps are long and more slender at the base than at the oral end (contracted polyp diameter approximately $1 \mathrm{~mm}$ ), and bright orange-yellow in color, both on the outside of polyps and the oral disk. Polyps are much smaller than Parazoanthus sp. 1401. Polyps are connected by a reduced, often almost stoloniferous coenenchyme. There are small white dots on the capitular ridges just below the edge of the oral disk and tentacles. Tentacles are long (>oral disk diameter) and slender, and number approximately 24-28 in total.

\section{Parazoanthus sp. 1401; Fig. $2 \mathrm{~g}$}

This species is currently only known from one area, Tarrafal Bay on Santiago Island. It was encountered on overhanging rock faces in 10-15 m depths and in a dark cave in $20 \mathrm{~m}$ depth. Polyps are cream-yellow often with a pink or orange hue, with a bright orange oral disk and a yellow mouth. The outer surfaces of polyps are encrusted with large amounts of coarse detritus of many different colors (black, white, gray), but the encrustations are not numerous enough to mask the yellow tissue color. Polyps extend free from a well-developed coenenchyme that is often stoloniferous. Tentacles number approximately 24 , and are slightly longer than the oral disk diameter (approx. 4-8 $\mathrm{mm}$ ). Contracted polyp diameter is approximately 1-4 mm, much larger than Parazoanthus sp. 269. Additionally, tentacles appear to be thicker at the base compared to other macrocnemic zoanthid species in the Cape Verde Islands, and taper to a slender ending. This species is often but not always associated with a yellow or orangish-red encrusting sponge.

\section{Family Hydrozoanthidae}

Like Parazoanthidae, all species in the family Hydrozoanthidae have a macrocnemic mesentery arrangement, with the $5^{\text {th }}$ mesentery from the dorsal directive perfect. However, molecular examinations demonstrated this group to be a monophyly very divergent from Parazoanthidae, and perhaps more closely related to 
Sphenopidae. Additionally, the two genera in this family either associate uniquely with hydrozoans (Hydrozoanthus spp.), or are found on rock substrate (Terrazoanthus spp), similar to many Zoanthidae and Sphenopidae species. Thus, based on both molecular and ecological data, this new family was recently erected (Sinniger et al., 2010).

\section{Terrazoanthus sp. 276; Fig. 2h}

This genus was recently erected (Reimer and Fujii, 2010) by grouping together hydrozoanthids that are found attached to rock or dead coral substrate, and not to hydrozoans as in the other genus of the family,
Hydrozoanthus. The Cape Verde Islands species was found only at one location (Murdeira Bay, Sal Island), on the underside of a large rock, suggesting a somewhat cryptic lifestyle similar to Terrazoanthus sinnigeri from the Galapagos Islands.

Polyps are relatively small (contracted polyps' approximate diameter $=3-4 \mathrm{~mm}$ ) and translucent pink in color, with large-sized encrustations peppering the outer surface of polyps. The coenenchyme appears to be somewhat reduced. Unfortunately, no in situ images of open polyps exist, and therefore the numbers of tentacles and oral disk coloration remain unknown for now. More specimens are needed to describe this species formally. 
